\title{
THE CASE FOR FULLY-FLEDGED PROFIT-LOSS SHARING BANKING
}

\author{
Muhammad Said Fathurrohman ${ }^{1}$ \\ ${ }^{1}$ Department of Islamic Economics, Faculty of Economics and Business, Universitas \\ Airlangga, Surabaya \\ Email: said@feb.unair.ac.id
}

\begin{abstract}
The original idea of Islamic banking is a two-tier profit-loss sharing banking. However, in practice Islamic banking only implements profit sharing in its funding side, while on the financing side profit sharing only take smaller share than that of fixed return financing, which is predominantly sale-basedfinancing. This paper aims to examine examine the issues in debt-like financing that are commonly used by Islamic banking. There are issues with the shariah validity of these types of financing due to involving multiple contracts. The issues in multiple contracts have economic implications, including risks and value added, which provide economic reasons to validate profit. Analysis on multiple contracts shows some conflict of rights and obligation implied by different contracts which are combined to form murabahah financing and musharakah mutanaqisah. The benefit analysis shows that both salebased financing and interest-paying credit takes profit from buyer for providing benefit of deferred payment. There is no real benefit of sale-based or rent-based financing for customer since Islamic banks never run real trading or rental business. This paper recommends Islamic banking to focus on its core as profit-sharing banking. Finally, this paper discusses some problems facing Islamic banking on the way transforming itself into fully-fledged profit-loss sharing banking and offers ideas to resolve it.
\end{abstract}

Keywords:Islamic Banking, Profit-Loss Sharing, Multiple Contracts 


\section{Introduction}

Initially, what is thought as Islamic banking is a banking system using profit-loss sharing (PLS) contract in the intermediation of public funds. Theoretical comparative studies between equity-based economy and interest-based economy generally reach conclusion of superiority of the former $[1,2]$.

Ironically, the actual Islamic financial system in practice is instead based mainly on debt-like contract, namely ijarah and murabaha.The characteristics of these modes of contract are very similar to that of interest-paying debt. When these contracts underlie the Islamic financial instituions in pracctice, we can no longer be sure that the Islamic financial system is more superior than the conventional financial system.

Equity-based system has both microeconomic and macroeconomic advantages over interest-based system. From microeconomic perspective, the equity-based system shares risks between the financer and financee, so that justice obtained by both parties. From macroeconomic perspective, equity-based system prevents one direction transfer of wealth from the financee to the financers. Equity-based system also makes funds channeled into the most productive sectors. The interest-based financial system and the actual Islamic financial system which is similar to the former do not have these advantages.

Contemporary Islamic economists tried to provide justification for the current Islamic financial system. They considered that murabahah and ijarah financing in the Islamic financial system differs substantially from the conventional loan. The main difference is in the requirement of underlying real asset for every Islamic financing. In fact, the practice of buying and selling (murabahah) financing is more prominent where the borrower then returns the goods in installments. However, this is where the practice of Islamic banking is criticized as being more symbolic, because the margins / profits achieved are similar to conventional banking(Dawam Rahardjo 2012).

In the conventional financing, debts are not always associated with real sector transactions. As a result, the growth of the financial sector could far exceed the growth in the real sector, rising financial bubbles whose pop usually causes economic crises. With the requirement of underlying real assets, murabaha and ijara financing will not be provided without the creation of added value in the real sector. Thus, the growth of the financial sector will be in line with the real sector and financial bubbles will not occur.

The underlying real assets also serve as protection for the fund owner in the time of default. The underlying real assets act as collateral which can be liquidated to pay off the remaining balance of loan.

This paper aims to examine the issues indebt-like financing that are commonly used by Islamic banking. There areissues with the shariah validity of these types of financing due toinvolving multiple contracts. The issues in multiple contracts have economic implications, including risks and value added, which provide economic reasons to validate profit. This paper argue for reforming Islamic bank into fully- 
fledged profit-loss sharing bank and offer some ideas to remove some obstacles in realizing it.

\section{Multiple Contracts}

Classical jurisprudence bequeath several contract modes which considered as valid according to Islamic law. Contemporary jurists have to mix more than one contract mode in order to deliver Islamic financial instruments which resembles conventional instruments. Murabahah financing usually combines ordered sale, deferred payment, and wakala. Ijarah based financing combines ijarah contract with other contracts. Musharakah mutanaqisah combines ijarah and musharakah.

National Shariah Board considers the general status of multiple contracts as permissible. Prophet's ban on three modes of multiple contracts is considered as qualification for the general status. The status of each case of multiple contracts should be evaluated whether any confusion or crash between rights and obligation implied by combined contracts (Hasanudin 2009). In Islam, a contract is also called a contract or agreement, namely the meeting of consent given by one side with the consent given by other side (Yunita D 2014). Akad or contract comes from Arabic which means a bond or conclusion, both visible (hissyy) and invisible bonds(ma'nawy)(Majd, n.d.)

Under the light of this method, Islamic banks' products which contain multiple contracts can be analyzed whether or not they cause a confusion on rights and obligation. In the case of murabahah financing, combination between sale and wakala may cause conflict between buyer's right and his duty as representative of bank to purchase goods from supplier. Buyer has right to get non defect goods and return it to the seller if any defect found in the goods. However, when buyers become representative of banks to purchase the desired goods from supplier, they share some, if not whole, responsibilities with the banks in case some defect found in the purchased goods. In contrast, banks would hardly be blamed because they barely hold, even see, the purchased goods.

Conflict of rights and obligation also exists in musharakah mutanaqisah. In the case of mortgage financing using this mode, financee acts both as a lessee and as an owner, jointly with bank, of the leased property. Potential conflicts arise in determining the rental price. A normal owner always tries to maximize the rental price in order to maximize his revenue. Banks usually behave as normal owner. In contrast, customers who share the ownership of property have interest to minimize the rental price because they are also the tenant. This will result in dispute, not only between owners and tenant, but also between owners each other. Which one of these two owners has greater control over the rental price? What will happen with the contracts if no price agreement between owner and tenant or between owners each other?

This potential conflict can be eliminated by fixing rental price from the time contract be made. However, this method raises other problem, namely potential injustice for either party because the predetermined rental price may be higher or lower than market rental price. As long as both parties have understood this price 
risk, they would not be dissatisfied.

\section{Risk and Value Added}

Contemporary jurists who support Islamic finance are reluctant to use the same name for Islamic financial product as its conventional counterpart. However, in practice the contract design of Islamic financial products very mimic the conventional counterparts. The jurists are forced to mimic conventional products to deal with legal constraints and to make Islamic product acceptable to common investors.

Murabahah financing contract is designed so that buyers may only bring bank's money and choose the desired goods at the chosen sellers on their own, like they usually do in conventional credit. For the banks, this contract design also minimizes their commercial risks, including the risk of defect product and unsold product.

The elimination of commercial risk rise a doubt on the validity of profit from this kind of murabahah financing. There is legal maxim "al-ghorm bil ghonm" (no pain no gain). If Islamic banks eliminate all risk which normally born by a seller, nothing can validate murabahah profit margin earned by the banks.

Some experts mention credit risk, operational risk, and interest risk may validate banks' profit. Credit risk come from the possibility of default of the financee. Interest rate risk come from the gap between Islamic banks' rate of return on deposits and conventional banks interest rate. If interest rate is much higher than Islamic banks' rate of return, Islamic banks' depositors may move their funds from Islamic deposits to conventional one.

Although the risks are potentially encountered by Islamic banks, nothing make the banks deserve for profit from their financing. Credit risk is born not only by murabahah financer, but also by the lender of loan. Nevertheless, a lender of loan is not allowed to take profit based on credit risk, neither are banks.

The benefit of delayed payment in selling may give the seller right to charge extra price. However, it is doubted that one may charge price margin if he/she actually do not offer benefits but the delayed payment itself. The ordinary seller provides several benefits to its customers other than delayed payments. Sellers bring goods from remote location to near location. Sellers also filter goods from defect ones in order to avoid buyers' complaint and returning goods. Sellers offer benefit of product variety which customers can choose.

In murabahah financing, Islamic banks pretend to be sellers who sell by credit. In fact, they do not add any benefit to consumer other than the delayed payments. Banks appoint their customers as representatives to purchase the products which customers want. The actual role of Islamic banks is no more than giving money to customers and collecting the delayed payments.

Indeed, if the buyers have known the sellers' suppliers and can purchase the goods in wanted quantity, they would better directly come to and buy from these suppliers. They no longer need any seller as intermediary between them and suppliers. The only reason why the customers of murabahah financing still need Islamic banks as intermediary is that Islamic banks enable them avoid paying in 
cash.

If Islamic banks want to use the murabahah contract, they must replace the way of thinking and behaving of ordinary banks with that of real sellers. Similarly in using ijarah contract, Islamic banks have to implement ways of thinking and behaving of the owner of the leased asset.

\section{Fully-Fledged Profit-Loss Sharing Banking}

The problem is that it is difficult to leave the ways of thinking and behaving when bank term is still attached. His name is also the Islamic banks, how could not think and act like a bank?

The status of financial institutions can be questioned when these institutions have jumped into the trading and leasing of operational assets. These institutions are no longer just dealing with money, and thus inappropriate for the named financial institution.

If reviewed from the history of banking in Indonesia, one cause of the banking crisis in 1997 is the channeling of public funds into the bank owner's business group. When the credit demanded by bank owners, business feasibility is no longer become consideration. If their businesses lose, they stop paying their debts and go bankrupt.

If Islamic banks run real business operations, this practice will be very similar to what practiced by private conventional banks experienced before the banking crisis. If Islamic banks are not good at running real business operations, they will only create big losses. Because in addition to having to compensate for the losses of the bank organization itself, Islamic banks will also be obliged to compensate for the losses of customers who are the rights of each of the bank's customers(Mohammad Wisno Hamin 2017).

In response to this, there are two options that can be taken by the Islamic banks. First, Islamic banks still provide murabahah and ijarah financing with a direct jump into the trading and rental operations. The problem Islamic banks have to face is the readiness of their human resources to conduct real business. A more difficult problem is to choose the kinds of commodities or assets they sold or rented. Banks should not run business conglomerate because it will lower its competitiveness, instead they should focus on some sectors.

However, it is now an international standard to prohibit banks use public deposits to finance business connected with the management and/or the owner of the banks. In the above concept, Islamic banks finance business which not only connected to management and owner, indeed the business is a part or a division of banks' business.

Alternatively, Islamic banks can return to its initial function as banks which do not run real business, but only dealing with fund management. Islamic banks restrict themselves to provide financing based only on mudarabah and musharakah contracts. Islamic banks may still perform oversight and provide consultancy to the financee to keep it from make a lose. Islamic banks' operations will be very similar to that of venture capital firms.

The difference between Islamic banks and venture capital firms are in the funding 
side, in which Islamic banks, like any bank, have rights to collect public funds. Other characteristics of Islamic banks that are inherent in the role as a bank is providing payment service, such as transfers, debit cards, and other banking services.

\section{Dealing with Asymmetric Information}

There are several difficulties arise in implementing fully-fledged profit-loss sharing banking. Many writers point to asymmetric information as the weakness of profit-loss sharing contract. Mudharib can hide the true profit to bank so that they pay less return on capital to bank.

The second weakness is especially pointed to contract design between depositors and current Islamic banks. Depositors are treated as silent partners in partnership or as shareholders in corporation. However, in the case of Islamic banks, depositors do not have rights for monitoring and appointing management.

The only control which depositors can exercise when banks doing fraud is by withdrawing their savings. However, Islamic bank are not required to report their financial statement and progress report to depositors. Most depositors do not have enough information about their banks except the service banks provide and the return on depositors' saving.

Conventional economists will directly point to predetermined interest loan to solve the asymmetric information problem. Predetermined interest protects depositors from banks' fraud, and likewise, protects banks from fiancées' fraud. Predetermined interest also serves as incentive-compatible contract. The fiancées will maximize their effort because they enjoy all excess profit and bear all loss.

Eventhough the asymmetric information argument for predetermined interest is valid, there are other considerations that should be taken into account. These considerations have been brought by Islamic economists who reject the validity of riba.

The equity consideration is the most important micro aspect of argument against predetermined interest. In the case when fiancée earn profit, there is no equity problem. The banks get predetermined interest and the financees earn all excess profit. But when fiancées lose, they bear the loss alone, while the banks and depositors keep earning predetermined interest.

Instead of proposing predetermined interest to solve asymmetric problems in profit-loss sharing contracts of Islamic banking, we would better improve the contract design to minimize the asymmetric information problem. This can be realized by give depositor right to appoint their representative for the board of commissioner. Through this way, depositors can keep management from serving only the shareholders' and/or their own interest.

\section{Liquidity Problem}

In the conventional banks, most of the liabilities is the obligation of third party funds. While the Islamic banks, most of the liabilities side is also from third-party funds, but the equity. Funds that dominated the third-party liabilities side of the 
conventional banks and Islamic banks are illiquid nature. While on the assets, both conventional banks and Islamic banks have tangible non-liquid assets.

Therefore, the issue of liquidity is always a scourge for the bank. At the time the net withdrawal of funds exceeding customer's cash reserves, the bank must bring in liquidity from other banks or the central bank. Banks that continue to experience liquidity shortages will ultimately fail to pay, unless saved by the banking authorities.

Other external sources of liquidity can not be depended in the long term because they cost far more expensive than third-party funds. In addition, in several circumstances, other banks do not want to lend their liquidity, because they also experience liquidity problem or they does not believe in the ability of requesting banks to pay back the loan.

A more appropriate technique is to convert illiquid assets into liquid ones. Conversion can be done by securitization. Profit-loss sharing financing can be securitized into certificates of ownership of financed company. This certificate is actually similar to but needs to be regulated differently from common stock.

Problems with the common stock are the rigid and costly regulations which small business cannot bear. Islamic banks can overtake the registration and supervision functions of government. Islamic banks help to make prospectus for the financed companies, market the certificate of ownership, distribute dividens, and monitor the health and the shariah compliance of companies' businesses.

Islamic banks can directly sell these certificates, or hold for themselves. The direct sale of certificates is equivalent to mudharabah muqayyadah contract, while the holding of them is equivalent to mutual fund. Even in the later mode, Islamic banks can sell their certificates any time they need, such as in the time of reserve shortage. However, banks may earn a capital gain or loss if the total market price of certificates is different from the amount of financing.

\section{Serving Needs for Credit Sale}

If Islamic banks provide financing only for results-based, then there would be no need to rent and transactions that are no longer tough filled by Islamic banks. Conventional banks meet both needs by providing interest-paying loans. What is Islamic economic solution to fulfill the needs of acquiring goods with deferred payment?

Actually, there are Islamic contracts which serve those needs. Ijarah and murabahah can be provided in basic form not by financial institutions like banks, but by companies operating real trading and rental business.

In fact, there are real companies that provide rental services and sale of these in credit. Credit sellersarenot as common as cash seller because of the difficulty in assessing the feasibility of non-cash buyer and selling credit needsmultiple fold of capital compared to cash selling.

Sellers that do not have enough capital and know-how for credit selling can make a partnership with Islamic banks, using either mudharabah or musharakah contracts. Banks can help providingsellers the required capital sell in installment. 
Banks can also help in checking the credithistory of buyers and in collecting installment payment from the buyers.

For illustration, suppose a buyer wants good bundle $X$ and selected non-cash payments. So the cost of $X$ will be paid by the Islamic bank to the sellers. The profit margin will be shared between the Islamic bank and the sellers based on agreed share ratio. The buyer can pay the installment through the bank. The sellersneed to wait untill the installment payment has been completed to get their share of profits, because until then there will still be risks that the buyer default on the payment.

\section{Conclusion and Recommendations}

This paper has examined the validity of the form of murabahah and ijarah financing which are commonly used by Islamic banking. The validity of financing form is evaluated through analyzing the consequence of multiple contracts, as well as the existence of risk and value added which can validate profit.

Analysis on multiple contracts shows some conflict of rights and obligation implied by different contracts which are combined to form murabahah financing and musharakah mutanaqisah. The value added analysis shows that both sale-based financing and interest-paying credit takes profit from buyer for providing benefit of deferred payment. There is no real benefit of sale-based or rent-based financing for customer since Islamic banking never run real trading or rental business.

However, it should be noted that the author do not intend and do not have capacity to give final judgement on the validity of financing modes examined in this paper. The actual intention is only to give some input from economic perspective to jurists expertized in this subject.

Anyway, there is no dispute for the validity of profit-loss sharing mode of financing. Indeed, this financing mode serve society the best to reach justice and prosperity. Islamic banks should become fully-fledged profit-loss sharing banking by providing only mudarabah and musharakah financing. Let the sale-based financing taken by actual sellers.

\section{References}

[1] Cecep M. Hakim, “Applying Islamic Jurisprudence Into Modern Banking: The Case of National Sharia Board, Indonesia". Proceeding of International Islamic Bank Conference, Monash University, 8-9 September 2003

[2] Dawam Rahardjo. 2012. "Ekonomi Politik Pembangunan." (Jakarta: LSAF, 2012), h. 3-32.

[3] Hasanudin. 2009. “'Multi Akad Dalam Transaksi Syariah Kontemporer Pada Lembaga Keuangan Syariah Di Indonesia: Konsep Dan Ketentuan (Dhawabith) Dalam Perspektif Fiqh'." UIN Syarif Hidayatullah. (Paper Presented on MES Goes to Campus at UIN Syarif Hidayatullah, Jakarta, 3 June 2009).

[4] Mahmoud A.El-Gamal, Islamic Finance: Law, Economics, and Practice. (Cambridge University Press, 2006)

[5] Majd, Fayruz Abadyy. n.d. “Majd Al-Din,." In Al-Qamus AlMuhit, Jilid 1. (Beirut: 
D Jayl),

[6] Mohamed Umer Chapra, "The Case Against Interest: Is It Compelling?"(paper presented at the International Conference on Islamic Banking and Finance held in Brunei, on 5-7 January 2004)

[7] Mohammad Wisno Hamin. 2017. "PERLINDUNGAN HUKUM BAGI NASABAH (DEBITUR) BANK SEBAGAI KONSUMEN PENGGUNA JASA BANK TERHADAP RISIKO DALAM PERJANJIAN KREDIT BANK." Lex Crimen Vol. VI/No.

[8] Mohsin S. Khan and Abbas Mirakhor, "The Financial System and Monetary Policy in an Islamic Economy," Islamic Economics 1 (1989): 39

[9] M. FahimKhan, "Comparative economics of some Islamic financing techniques," Islamic Economic Studies 2(1994): 35

[10] Siddiqi, Muhammad N.,"Monetary Theory of Islamic Economics”. http:/wwww.financeinislam.com/article/1_36/1/8

[11] Yunita D. 2014. "TINJAUAN HUKUM KONTRAK PRINSIP SYARIAH DIBANDINGKAN DENGAN SISTEM HUKUM PERDATA." Universitas Tadulako. 